УДК 621.643

\title{
МОДЕРНІЗАЦІЯ СИСТЕМИ ОПАЛЕННЯ БУДІВЛІ З ВИКОРИСТАННЯМ ТЕПЛОВОГО НАСОСА ТИПУ «ПОВІТРЯ-РІДИНА»
}

\author{
Басок Б. І., чл.-кор. НАН України, Недбайло О.М., канд. техн. наук, Ткаченко М.В., Божко І.К., \\ Лисенко О.М., Луніна А.О.
}

Інститут технічної теплофізики НАН України, вул. Желябова, 2а, м.Київ, 03680, Україна

Наведений опис оригінального технічного рішення щодо використання теплового насосу для опалення частини адміністративної будівлі. Розроблена гідравлічна схема підключення та виконаний підбір теплотехнічного обладнання до неї. Проаналізована енергетична ефективність використання теплового насоса в опалювальний період.

Бібл. 5, табл. 1, рис. 5.
Приведено описание оригинального технического решения относительно использования теплового насоса для отопления части административного здания. Разработана гидравлическая схема подключения и выполнен подбор теплотехнического оборудования к ней. Проанализирована энергетическая эффективность использования теплового насоса в отопительный период.

Ключові слова: тепловий насос, енергозбереження, система опалення, індивідуальний тепловий пункт.

Bcmyn.

Енергозбереження за рахунок підвищення ефективності використання енергії та залучення в енергетичний баланс відновлювальних низькопотенційних джерел енергії $€$ одним 3 найважливіших завдань для комунальної теплоенергетики України. Впровадження таких новітніх технологій, зокрема із застосуванням теплових насосів, дозволить значно скоротити обсяги споживання органічних паливних ресурсів та заміщувати їх природними джерелами теплоти.

Забезпечення теплопостачання будинків різного призначення на основі технологій із використанням теплових насосів є найбільш поширеним у сучасній світовій альтернативній енергетиці. Такі системи характеризуються високою енергетичною ефективністю, автономністю від теплопостачальних мереж, а також екологічною безпекою технології та обладнання, що використовуються.

В Інституті технічної теплофізики впроваджено ряд проектів, що мають за мету скорочення споживання теплової енергії на потреби опалення адміністративних будівель. Се- ред таких проектів - розробка та встановлення індивідуального теплового пункту (ITП) оригінальної конструкції [1], модернізація частини системи опалення корпусу №1 3 встановленням теплового насоса типу «грунт-вода» та типу «повітря-вода» [2] та ін.

Основні результати. На рис. 1 представлена принципова гідравлічна схема модернізації існуючої централізованої системи опалення триповерхової адміністративної будівлі корпусу №1 ІТТФ НАН України з використанням теплового насоса «повітря-вода». Фотографія оригінальної схеми підключення теплового наcoca показана на рис. 2. Трубна система із приладами вимірювання, контролю та автоматики розміщена у виставковій залі інституту.

Модернізація системи опалення здійснена шляхом інтеграції теплового насосу 7 IVT Optima 1700 (Швеція) (рис. 3) типу «повітрявода» вихідною теплової потужністю 16 кВт в існуючу систему централізованого опалення будівлі. Модернізована система може працювати як від індивідуального теплового пункту, використовуючи теплоту як від районної котельні 
або ТЕЦ за класичною схемою, так і від теплового насосу. При роботі системи за традиційною проектною схемою для уникнення забруднення трубопроводів та опалювальних приладів від теплоносія, що надходить 3 теплової мережі встановлено барботажний сепаратор бруду і газів 2 Spirovent.

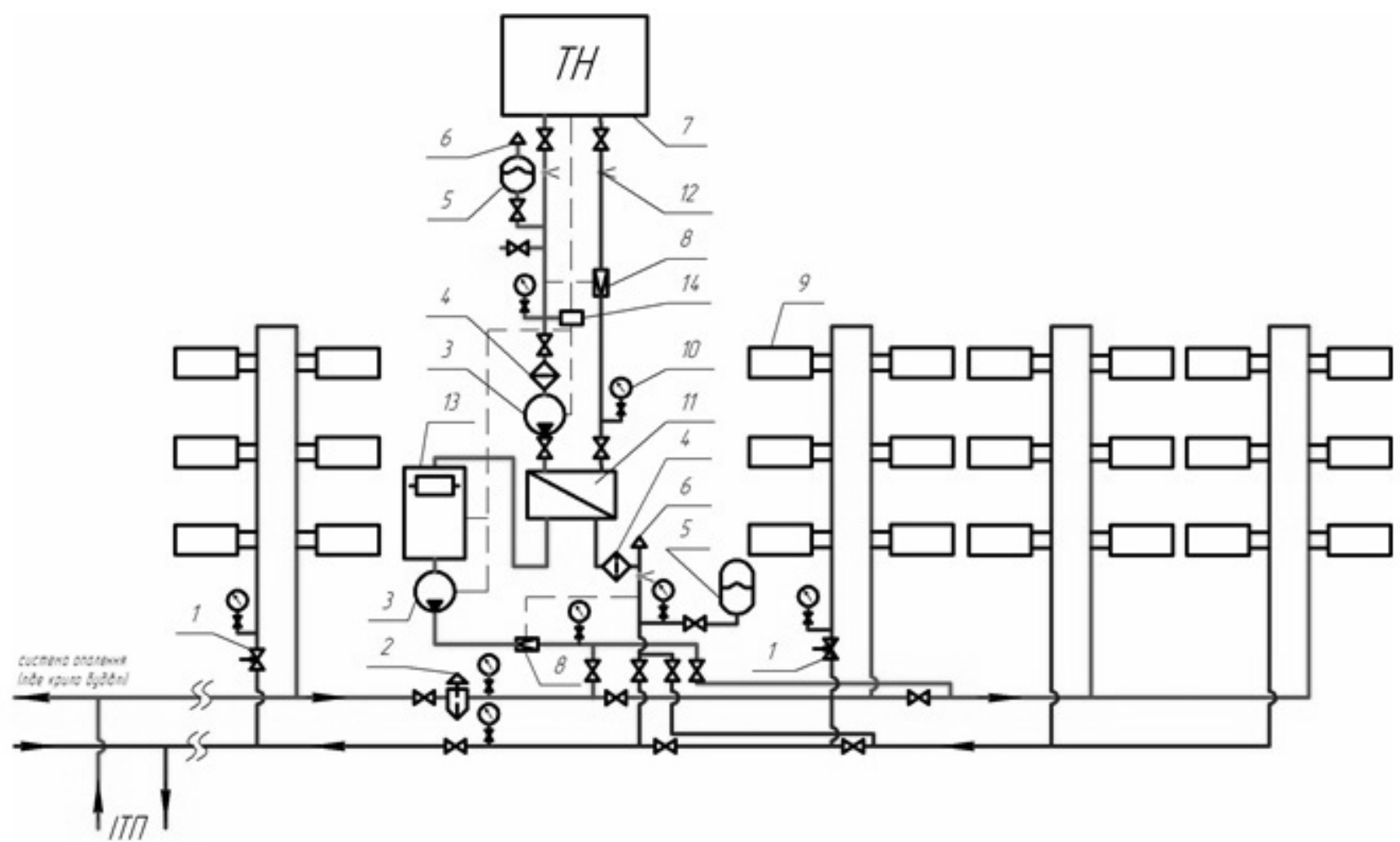

Рис. 1. Принципова схема модернізації системи опалення, тут:

1 - клапани балансувальні; 2 - барботажнний сепаратор; 3 - циркуляційні насоси;

4-фільтри сітчасті; 5 -баки розиирювальні мембранні; 6-повітроспускники;

7 - тепловий насос «повітря-вода» (TH); 8 -лічильник теплоти;

9 -радіатор системи опалення; 10 -манометр; 11 - пластинчатий теплообмінник, 12 - датчики температури; 13 - електричний котел; 14 - датчик тиску.

При роботі системи від теплового насосу частина контуру типової системи опалення радіаторного типу відключається від індивідуального теплового пункту за допомогою запірної арматури, при цьому для гідравлічного урівноваження циркуляції по стояках старої системи передбачені балансувальні клапани 1.

Оскільки частина трубопроводів від теплового насоса проходить ззовні будівлі, тому для уникнення замерзання в них теплоносієм $\epsilon$ водний розчин пропіленгліколю «Тепро-20» ТУ В 24.1-2464717949-001:2005, який має здатність не замерзати до температури - 22 ${ }^{\circ} \mathrm{C}$. Контур 3 розчином пропіленгліколю (те- плового насоса) гідравлічно роз'єднанно 3 контуром системи опалення через пластинчатий теплообмінник 10 Alfa Laval. При цьому, можливе опціональне відключення від теплової мережі шістьох або чотирьох стояків (в залежності від необхідності підтримування теплового режиму будівлі) із радіаторами 9 за допомогою запірної арматури.

При роботі установки на шість стояків, загальна опалювана площа складає 288 м². Підтримання нормативної температури при опаленні приміщень такої площі тепловим насосом можливо лише в перехідні періоди - жовтень та квітень, коли середньомісячна температура 
в м. Києві відповідно $7,9{ }^{\circ} \mathrm{C}$ та $8,9{ }^{\circ} \mathrm{C}$ [3], при якій мінімальні теплові втрати будівлі та максимальна теплопродуктивність ТН. При роботі теплового насосу на 4 стояки системи опалення, опалювана площа становить $162 \mathrm{~m}^{2}$, що дозволяє використовувати тепловий насос для теплозабез- печення протягом всього опалювального періоду.

Зовнішній блок теплового насосу встановлено якомога ближче до приміщень, які він буде опалювати, на даху входу до корпусу. Також здійснено обов'язкове утеплення магістральних трубопроводів для мінімізації теплових втрат.

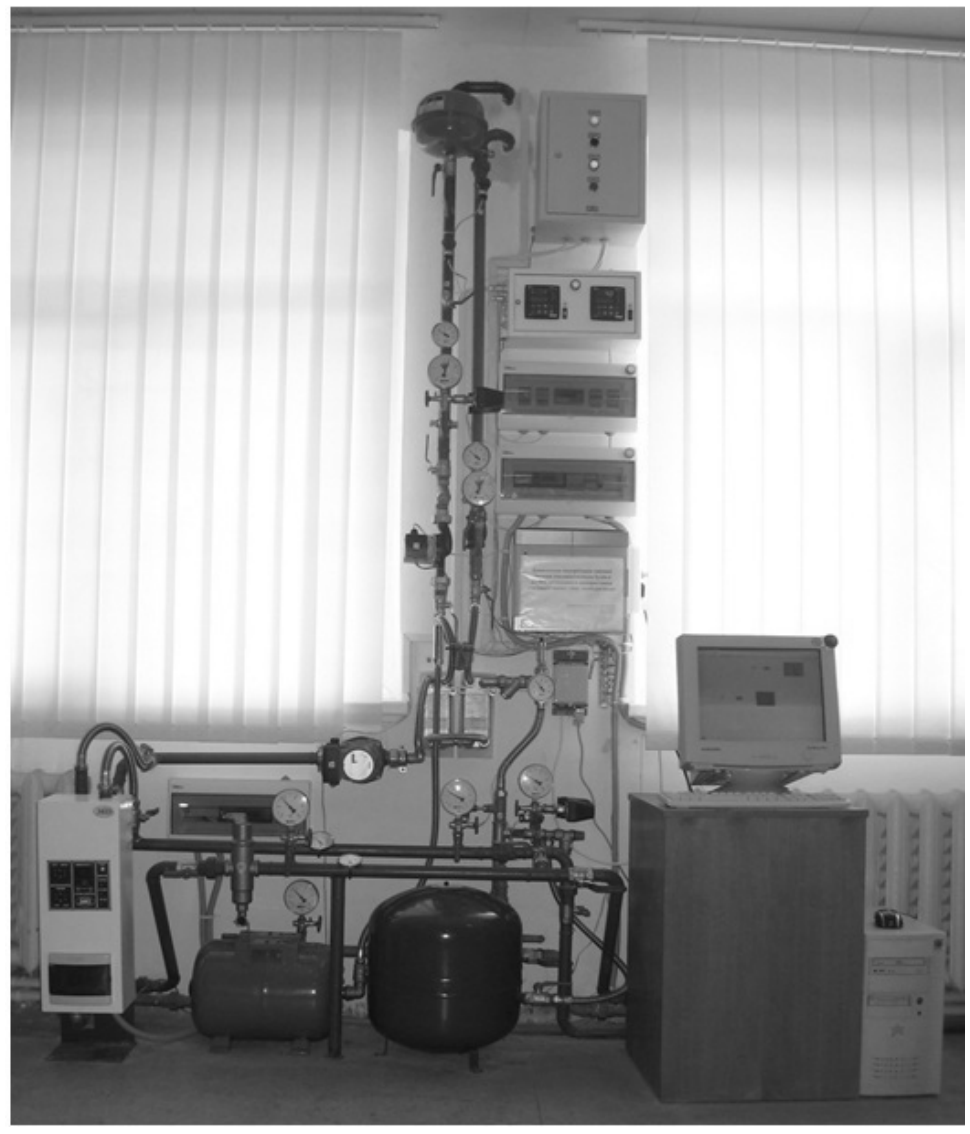

Рис. 2. Оригінальна схема підключення теплового насосу типу «повітря-рідина».

Перед запуском модернізованої системи теплопостачання була виконана ретельна промивка старої системи опалення барботажним способом із застосуванням бульбашкового водоповітряного потоку та хімічних реактивів для видалення відкладень. При заповненні контурів та їх роботі повітря видаляється за допомогою повітрьоспусників 6. Циркуляція в обох контурах iз заданої витратою забезпечується, відповідно, насосами 3 Wilo-Star-RS 25/6 (контур системи опалення) та Wilo-Top-S 25/10 (контур теплового насоса) 3 очищенням теплоносія у сітчастих фільтрах грубої очистки 4. Передбачене автоматичне відключення циркуляційних та теплового насосів за допомогою датчику тиску 14 у разі розгерметизації контурів та втраті тиску. Для компенсації об'ємного розширення теплоносія застосовуються дві ємкості 5, об'ємом 4 (контур теплового насоса) та 50 літрів (контур системи опалення). Об'єм баків розраховано відповідно до об'єму теплоносія в контурі, його коефіцієнта температурного розширення та температурного графіка роботи системи опалення.

Вимірювання кількості теплоти, яка витрачається для опалення приміщень, здійснюється окремо у кожному 3 контурів тепловими лічильниками 8, що дає змогу оцінити втрати теплоти у магістральних трубопроводах та ефективність роботи теплообмінника. Електричний котел 13 «Еко-Компакт» 


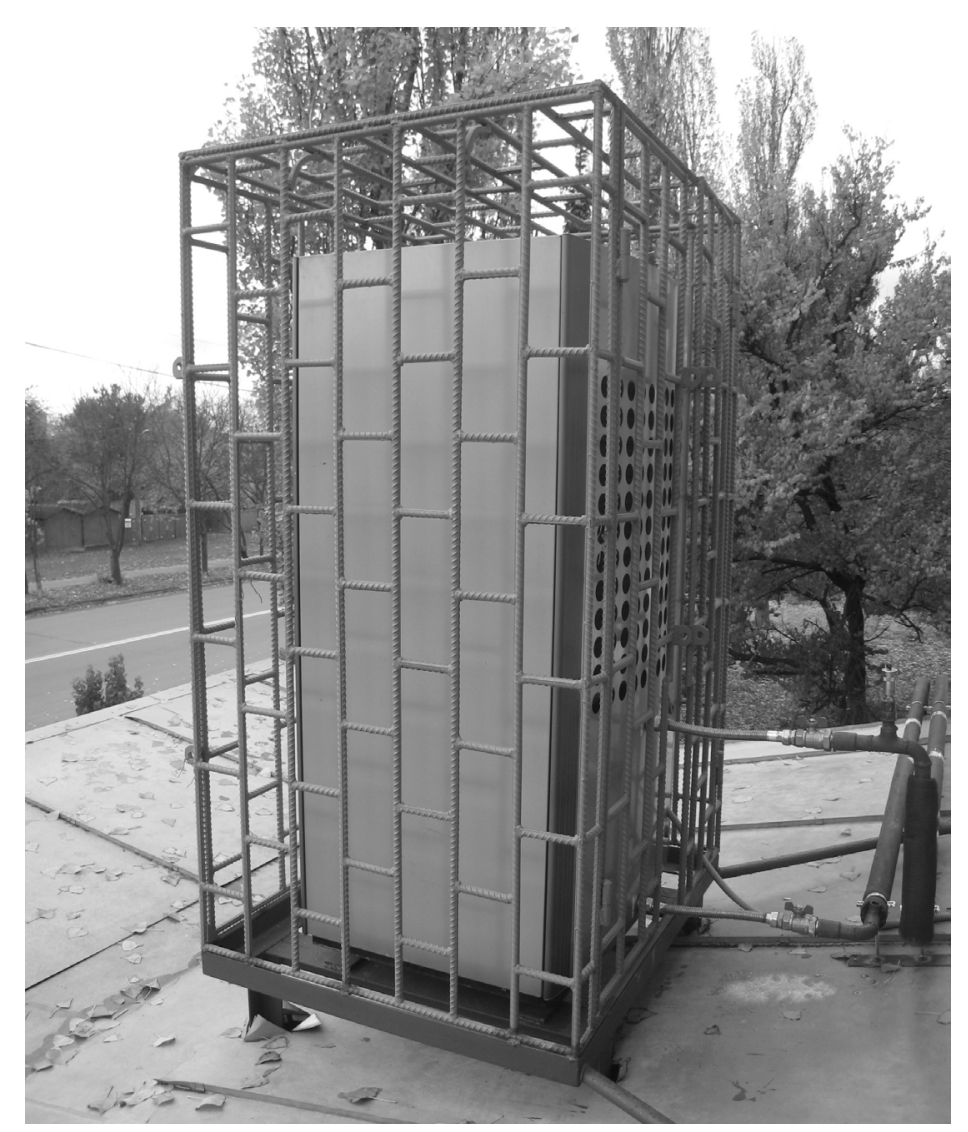

Pис. 3. Тепловий насос IVT Optima 1700.

К-6/6-380 (Україна) тепловою потужністю 6 кВт призначений для резервного (аварійного) та пікового теплопостачання у разі неможливості роботи теплового насоса або в якості додаткового нагрівача при його недостатній теплопродуктивності. Для проведення досліджень ефективності роботи теплового насосу температура теплоносія у прямому та зворотному трубопроводах обох контурів вимірюється термоперетворювачами типу ТСП-002к та реєструється вторинними контрольними приладами. Для автоматизації роботи теплового насосу використовуються датчики температури:

- зовнішнього повітря,

- повітря у середині приміщення,

- теплоносія у прямому та зворотному трубопроводах.

Інтервал роботи теплового насоса показаний на рис. 4. Витрата теплоносія у контурі ТН склала 2,1 м³/год. Витрата теплоносія у опалювальному контурі, відповідно, 18,2 м3 год.

На рис. 5 приведено інтервал роботи індивідуального теплового пункту [4].
Порівнюючи вищевказані два графіки (рис. 4 та рис. 5) можна зробити наступні висновки:

- експериментальна установка на основі теплового насоса «повітря-вода» та індивідуальний тепловий пункт оригінальної конструкції забезпечують надходження необхідної кількості теплової енергії для підтримання нормативних значень температури внутрішнього повітря;

- обидві установки працюють на принципі багатократного збільшення циркуляції теплоносія контуру опалювальних приладів;

- найбільші показники економії теплової енергії припадають на «перехідний» період, коли температура навколишнього повітря близька, чи вища за нуль градусів. Це зумовлено тим, що в цей період тепловий насос має найвищий показник коефіцієнту перетворення енергії.

За експериментальними даними були обчислені середні питомі теплові втрати будівлі та встановлена економія теплової енергії при використанні теплового насосу типу «повітрявода»[5]. Всі дані зведені до таблиці 1. 


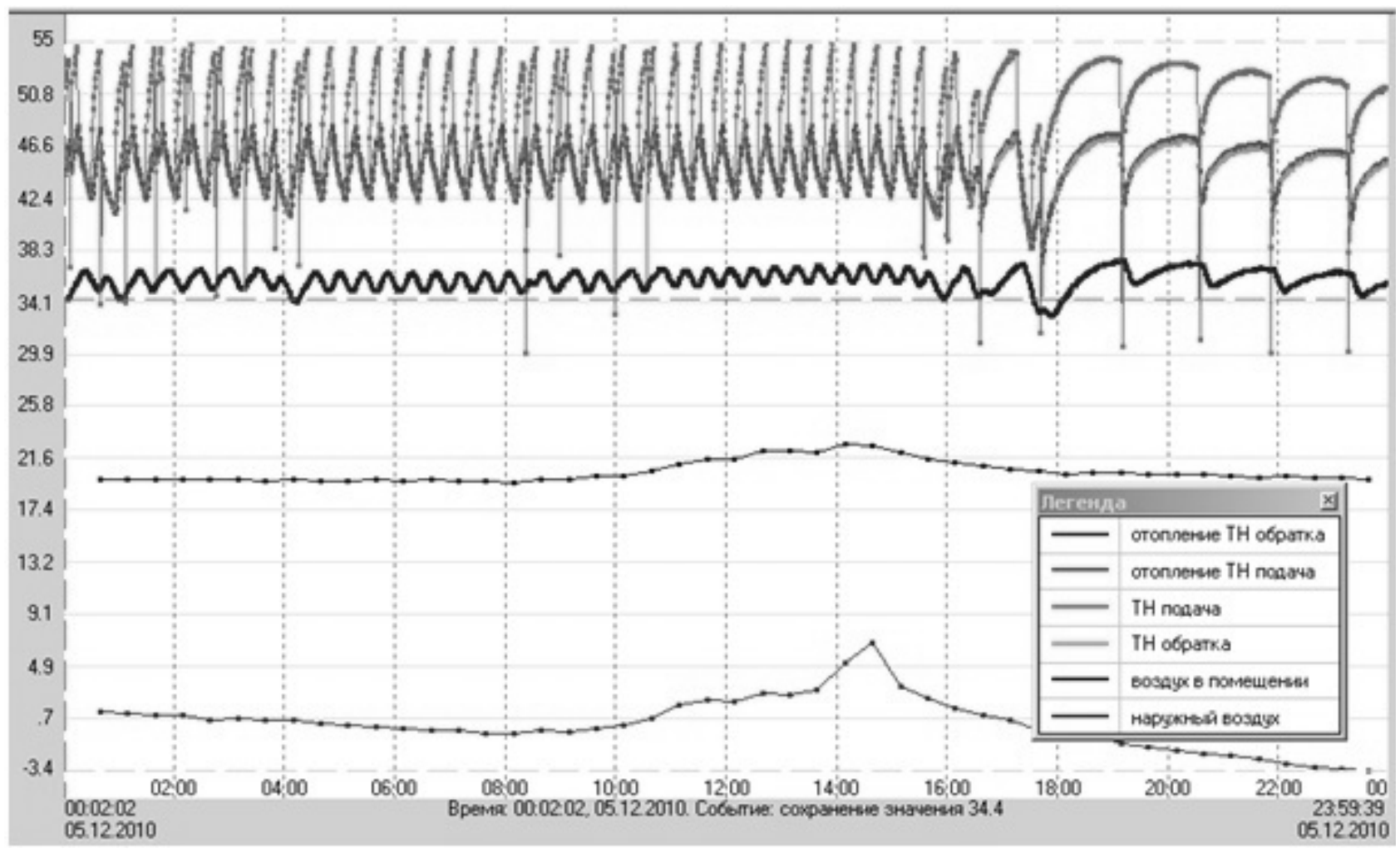

Рис. 4. Інтервал роботи теплового насоса.

吾

80

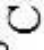

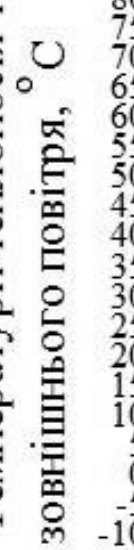

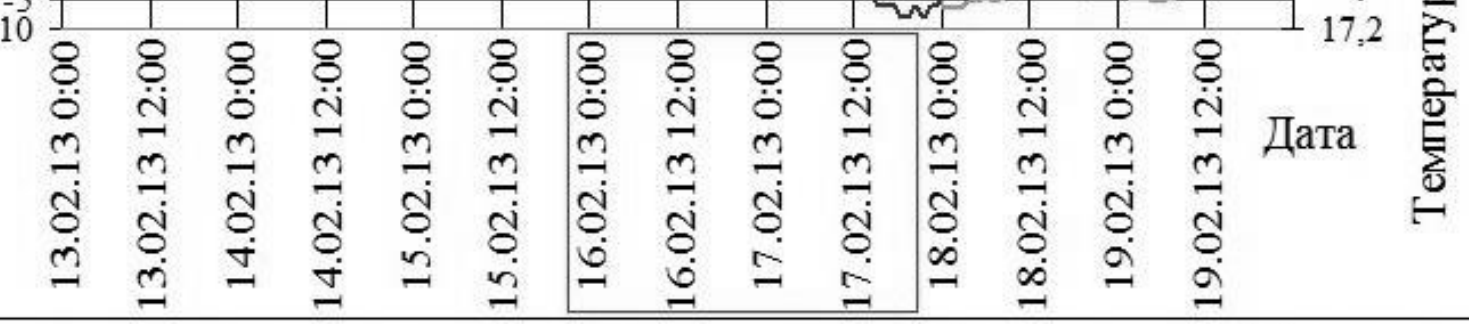

$-\mathrm{t}$ под. -

Рис. 5. Інтервал роботи індивідуального теплового пункту. 
Таблиця 1. Розрахунковий економічний ефект від встановлення теплового насосу потужністю 16 кВт в будівлі з максимальними тепловтратами 208 кВт

\begin{tabular}{|c|c|c|c|c|c|c|c|}
\hline Місяць року & жовтень & листопад & грудень & січень & лютий & березень & квітень \\
\hline $\begin{array}{c}\text { Середньомісячна температура } \\
\text { в м. Києві, }{ }^{\circ} \mathrm{C}\end{array}$ & 7,9 & 1,8 & $-2,0$ & $-4,3$ & $-3,3$ & 1,3 & 8,9 \\
\hline $\begin{array}{c}\text { Вихідна потужність теплового } \\
\text { насосу, кВт }\end{array}$ & 15 & 13 & 11,5 & 11 & 11,3 & 12,8 & 15,5 \\
\hline $\begin{array}{c}\text { Середні питомі тепловтрати } \\
\text { будівлі, кВт }\end{array}$ & 65 & 80 & 100 & 110 & 107 & 97 & 65 \\
\hline $\begin{array}{c}\text { Економія теплової } \\
\text { енергіі, \% }\end{array}$ & 23 & 16 & 11 & 10 & 10 & 13 & 24 \\
\hline
\end{tabular}

Виходячи 3 даних в табл. 1 - за опалювальний період середня економія теплової енергії при встановленні теплового насосу потужністю 16 кВт, в адміністративній будівлі, становить близько $15 \%$. Тому доцільно використовувати теплові насоси при реконструкції, термомодернізації та будівництві нових громадських та адміністративних будівель різного призначення (школи, дитячі садки, корпуси інститутів та ін.).

\section{ЛІТЕРАТУРА}

1. Лисенко О.М. Оцінка окремих режимів експлуатації індивідуального теплового пункту // Пром. теплотехніка. - 2012. - Т. 34, № 7. C. 95-99.

2. Б.І. Басок, Т.Г. Бєляєва, А.Р. Коба, М.В. Ткаченко, О.М. Недбайло, М.А. Хибина, А.О. Луніна, І.О. Кочешев, Ю.С. Ніколаєнко. Комплексна модернізація типової системи теплопостачання будівлі на основі використання теплового насосу типу «повітря-вода» // Пром. теплотехни- ка. - 2009. - Т. 31, № 7. - С. 19-21.

3. Справочник по климату СССР. Вып. 10, Часть II. Температура воздуха и почвы. - Л.: Гидрометеоиздат, 1987. - 608 с.

4. Басок Б.І., Лисенко О.М., Приємченко B.П., Андрейчук С.В. Особливості теплозабезпечення адміністративної будівлі на основі індивідуального теплового пункту // Будівельні конструкції: Міжвідомчий науково-технічний збірник наукових праць (будівництво) / Державне підприємство «Державний науково-дослідний інститут будівельних конструкцій» Міністерства регіонального розвитку, будівництва та житлово-комунального господарства України - 2013. Вип. 77. - К: ДП НДІБК. - С. 184-188.

5. Долінський А.А., Басок Б.І., Бєляєва Т.Г. та ін. Система автономного опалення 3 використанням теплового насосу на базі централізованого теплопостачання // Патент України на корисну модель U2009 №13243. 
MODERNIZATION OF BUILDING'S HEATING SYSTEM USING HEAT PUMP TYPE "AIR-LIQUID"

\section{Basok B.I., Nedbaylo A.N., Tkachenko M.V., Bozhko I.K., Lysenko O.N., Lunina A.A.}

Institute of Engineering Thermophysics NAS of Ukraine, 03680, Ukraine, Kyiv. Str. Zhelyabova 2a.

The description of original technical decision of using heat pump for heating part of administrating building is described. The hydraulic connection scheme is developed and selection of heat devices is executed for it. The energy efficiency for using heat pump in heating season is analyzed.

References 5,tables 1, figures 5.

Key words: heat pump, energy, heating, individual heating unit.

1. Lysenko O.N. Evaluation of individual operating modes Heating Substations // Prom. heating engi-neer. - 2012. - Vol 34, № 7. - P. 95-99.
2. B.I. Basok, T.G. Belyaeva, A.R. Koba, M.V. Tkachenko, A.N. Nedbaylo, M.A. Hybyna, A.O. Lunina, I.A. Kocheshev, J.E. Nikolaenko. Complex modernization typical building heating system through the use of heat pump type "airwater" // Prom. teplotehnyka. - 2009 - Vol 31, №7. P. 19-21.

3. Directory on climate USSR. Vol. 10, Part II. The temperature of air and soil. - L .: Gidrometeoizdat, 1987. -608 p.

4. Basok B.I., Lysenko O.N., Pryyemchenko V.P., Andreychuk S.V. Features heating administrative building on the basis of individual heating unit // Building structures: Interdepartmental scientific and technical collection of scientific works (construction) /State Enterprise "State Research Institute of Building Constructions" of the Ministry of Regional Development, Construction and Housing and Communal Services of Ukraine - 2013. Vol. 77 - K: SE NIISK. - P. 184-188.

5. Dolinsky A.A., Basok B.I., Belyaeva T.G. etc. Indirect heating using heat pump based district heating // Patent of Ukraine for useful model U2009 №13243.

Получено 04.08.2015 Received 04.08.2015 